Article

\title{
Investigation of the Pd Nanoparticles-Assisted Chemical Etching of Silicon for Ethanol Solution Electrooxidation
}

\author{
Olga Volovlikova ${ }^{1, *}$, Gennady Silakov ${ }^{1}$, Sergey Gavrilov ${ }^{1}$, Tomasz Maniecki ${ }^{2}$ and \\ Alexander Dudin ${ }^{3}$ \\ 1 Institute of Advanced Materials and Technologies, National Research University of Electronic \\ Technology (MIET), Moscow 124498, Russia; mr.komrad-13@ya.ru (G.S.); pcfme@miee.ru (S.G.) \\ 2 Institute of General and Ecological Chemistry, Lodz University of Technology, Zeromskiego 116, \\ 90-924 Lodz, Poland; tmanieck@p.lodz.pl \\ 3 Institute of Nanotechnology of Microelectronics of the Russian Academy of Sciences (INME RAS), \\ Moscow115487, Russia; dudin_aa@icloud.com \\ * Correspondence: 5ilova87@gmail.com; Tel.: +7-903-292-1507
}

Received: 7 November 2019; Accepted: 10 December 2019; Published: 12 December 2019

\begin{abstract}
The formation of porous silicon by $\mathrm{Pd}$ nanoparticles-assisted chemical etching of single-crystal $\mathrm{Si}$ with resistivity $\rho=0.01 \Omega \cdot \mathrm{cm}$ at $25^{\circ} \mathrm{C}, 50{ }^{\circ} \mathrm{C}$ and $75^{\circ} \mathrm{C}$ in $\mathrm{HF} / \mathrm{H}_{2} \mathrm{O}_{2} / \mathrm{H}_{2} \mathrm{O}$ solution was studied. Porous layers of silicon were studied by optical and scanning electron microscopy, and gravimetric analysis. It is shown that por-Si, formed by Pd nanoparticles-assisted chemical etching, has the property of ethanol electrooxidation. The chromatographic analysis of ethanol electrooxidation products on por-Si/Pd shows that the main products are $\mathrm{CO}_{2}, \mathrm{CH}_{4}, \mathrm{H}_{2}, \mathrm{CO}, \mathrm{O}_{2}$, acetaldehyde $(\mathrm{CHO})^{+}$, methanol and water vapor. The mass activity of the por-Si/Pd system was investigated by measuring the short-circuit current in ethanol solutions. The influence of the thickness of porous silicon and wafer on the mass activity and the charge measured during ethanol electrooxidation was established. Additionally, the mechanism of charge transport during ethanol electrooxidation was established.
\end{abstract}

Keywords: porous silicon; Pd nanoparticles-assisted chemical etching; etching rate; ethanol electrooxidation

\section{Introduction}

Technological innovation leads to an increase in energy and natural resources consumption, in particular, natural gas. Continuous consumption of non-renewable resources leads to their exhaustion. There is a need to develop and make use of alternative energy sources, based on environmentally-friendly technologies, because of natural resources limitations. Development of new alternative energy sources will allow us to receive scientific and technical results, with technologies which provide transition to resource-saving energy. One of the prospective directions in the resource-saving power area is the fuel element and portable electrochemical energy generators. They have many advantages: portability, high efficiency, small level of harmful emissions and quietness [1]. Nowadays, an interesting and prospective direction in the resource-saving power area is ethanol as fuel and a power source for the electric current generators [2].

Transformation to electric power is due to direct ethanol oxidation in the cell. It allows the simplification of the fuel supply system because of high specific energy of liquid alcohols, providing a short circuit in an environmentally-friendly cycle of transformation of energy in the natural scale due to a number of alcohols. The ethanol can be produced in biosystems in almost unlimited volumes [3]. The oxidation product of ethanol is $\mathrm{CH}_{4}$. 
Recent studies for alternative fuels indicate a growing interest in the development of small fuel cells and energy generators based on porous silicon due to a few advantages: high specific surface; strong chemical loading ability of the surface; the possibility of changing the surface morphology of the porous layers at the nano- and micro levels; simplicity and low cost of manufacture and compatibility with silicon integrated technology [4]. The plasma chemical etching for porous silicon formation is widely used. This method is characterised by a high complexity of hardware provided [5]. Chemical etching in solutions of alkalis or acids is a cheaper method for porous Si formation. Porous Si is usually formed by anode etching in HF solutions [6-8]. However, this method means individual treatment of wafers.

In recent years, special development was received by the chemical etching induced by noble metals ( $\mathrm{Ag}, \mathrm{Au}, \mathrm{Pt}$, and $\mathrm{Pd}$ ) [9-12]. This method is simple and enables carrying out group treatment of wafers that reduces the price of the technology of porous silicon formation. Besides, this method allows the production of porous silicon with a wide range of geometrical sizes by using a form and type of a metal mask. The thickness of the porous silicon is defined by the etching duration, electrolyte composition, and the metal amount. The MACE (metal-assisted chemical etching) method enables the production of a noble metal/porous silicon structure that combines the functions of both the anode and cathode of the generator's active element and fuel cell. This structure is called the Schottky junction (Schottky barrier). In work by Bin Zhu $[13,14]$ a hydrogen fuel cell based on the Schottky barrier (metal, p-type semiconductor) was described.

Porous silicon functionalised with noble metals is of undoubted scientific and practical interest as an object for the production of new energy generators. Simplifying the design by switching to a single-layer functional structure will increase the productivity and reduce the cost of the finished device. Conducting studies of the electrocatalytic ethanol oxidation using the cathode/anode structure, based on Pd clusters in a porous layer, allows producing an environmentally-friendly and resource-saving energy sector. The efficiency of creating a structure is associated with a high specific surface area of the porous silicon, and size effects of a metal catalyst during the ethanol electrooxidation. It occurs on the local nano- and micro-regions of the anodes/cathodes inside of porous silicon. Understanding the electro-catalytic activities of the ethanol on the Pd/por-Si structure is very important for developing more active catalysts for the direct-ethanol generators. The purpose of the work is establishment of the influence of the porous layer thickness and porosity formed by Pd nanoparticles-assisted etching on the duration of gas evolution, and ethanol electrooxidation mass activity for different ethanol-based electrolytes.

\section{Materials and Methods}

Boron doped $p$-type silicon wafers with $\left(\begin{array}{lll}1 & 0 & 0\end{array}\right)$ orientation and resistivity of $0.01 \Omega \cdot \mathrm{cm}$ were cleaned as follows: (i) dipping into $\mathrm{H}_{2} \mathrm{SO}_{4}(98 \%): \mathrm{H}_{2} \mathrm{O}_{2}(30 \%)$ (in volume 1:1) solution, then (ii) into $\mathrm{HF}(40 \%): \mathrm{H}_{2} \mathrm{O}$ (in volume 1:4) solution to remove native oxide and finally, (iii) into pure ethanol. The cleaned wafers were cut into pieces $3 \times 3 \mathrm{~cm}^{2}$. The samples were placed in a Teflon cell. The samples were immersed into solution $\mathrm{PdCl}_{2}: \mathrm{HCl}(0.5 \mathrm{~g} / \mathrm{L} \mathrm{PdCl} 2,20 \mathrm{~mL} / \mathrm{L} \mathrm{HCl})$ for $30 \mathrm{~min}$ at $25^{\circ} \mathrm{C}$ for Pd film deposition. The por-Si formation was performed in solution $\mathrm{HF}(40 \%): \mathrm{H}_{2} \mathrm{O}_{2}(30 \%): \mathrm{H}_{2} \mathrm{O}(25: 10: 4$ in volume) at $T=25,50$ and $75^{\circ} \mathrm{C}$. Porosity was calculated by gravimetric analysis. Samples with area $S$ were weighed before etching $\left(m_{1}\right)$. Then non-polished side of the sample was covered by varnish and dried in the air. The etching duration was 30-120 min. Then, samples were cleaned in ethanol and dried at $65{ }^{\circ} \mathrm{C}$. The varnish was removed and the samples were weighed $\left(m_{2}\right)$. Por-Si was dissolved in a water solution of $\mathrm{NaOH}$ and weighed $\left(m_{3}\right)$. Porosity was calculated by the equation:

$$
P=\frac{m_{1}-m_{2}}{m_{1}-m_{3}} \times 100 \%
$$

where $m_{1}$ and $m_{2}$ are the sample's masses before and after etching and $m_{3}$ is the sample mass after por-Si dissolution. Samples were etched in the same conditions because of the multi-sectional Teflon cell. 
The duration of filling of the same gas volume $(2.4 \mathrm{~mL})$ during ethanol electrooxidation (EEO), with different $\mathrm{C}_{2} \mathrm{H}_{5} \mathrm{OH}$ concentrations, was fixed. The gas volume, as a result of the ethanol electrooxidation by $2.5 \mathrm{~cm}^{2}$ samples, was measured using a cell (Figure 1). The essence of the method is the displacement of water by the gas, under a glass cell.

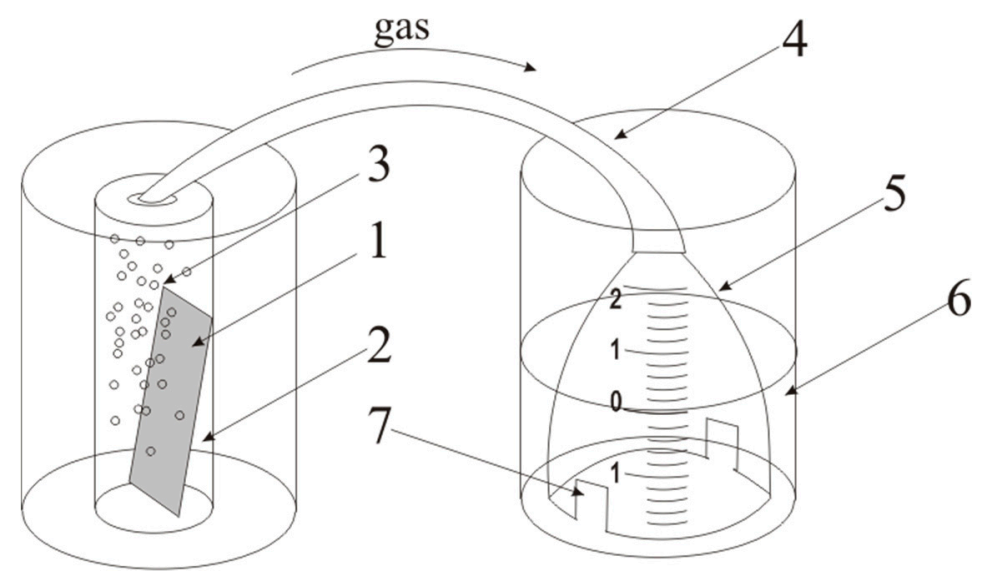

Figure 1. Schematic presentation of cell for gas volume measurement: (1) sample, (2) ethanol solution, (3) gas, (4) flexible tube, (5) cell, (6) glass cell, (7) holes.

The sample (1) was placed into a glass cell with ethanol solution (2). Gas evolution (3) occurs. Then, gas follows on a flexible tube (4) in cell (5) located in glass cell (6) with water (level 0). Then the gas displaces water from cell through the holes (7) and the level changed. The displaced water volume equals to gas volume evolved during a certain time $V_{\text {water }}=V_{\text {gas }}$.

The cell was filled multiple times to calculate the gas evolution rate $v$. It was calculated by the equation:

$$
v=\frac{V_{\text {gas }}}{t}
$$

where $V_{\text {gas }}$ is the gas volume and $t$ is the duration of the gas evolution.

Sample surface morphology was investigated by optical and scanning electron microscopy (Carl Zeiss Axiovert 40 MAT (Carl Zeiss Group, Oberkochen, Germany) and Helios NanoLab 650 (Thermo Fisher Scientific, Hillsboro, OR, USA)). Energy-dispersive X-ray (EDX) spectroscopy was performed on FEI Helios (FEI, Hillsboro, OR, USA) with an EDAX Octane Elite super EDS System (Octane Super, Mahwah, NJ, USA). The short-circuit current during etching in the galvanic cells and the mass activity as a function of EEO time were measured with a digital multimeter (UNI-T UT61C, UNI-T Group Ltd.,

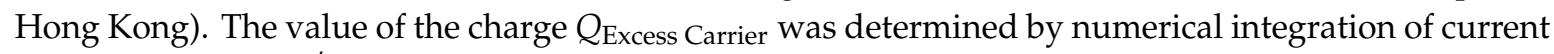
versus time, $Q=\int_{0}^{t} J \mathrm{~d} t$. The composition and conductivity of ethanol solutions for mass activity measurements are presented in Table 1. $\mathrm{pH}$ equals to 2 made by adding $\mathrm{H}_{2} \mathrm{SO}_{4}$ into ethanol solution.

Table 1. Solution properties.

\begin{tabular}{cccc}
\hline Solution & Ethanol/Water (Volume Ratio) & $\mathbf{p H}$ & Conductivity \\
\hline 1 & $10 / 90$ & 2 & $5.00 \mathrm{mS} / \mathrm{cm}$ \\
2 & $50 / 50$ & 2 & $2.84 \mathrm{mS} / \mathrm{cm}$ \\
3 & $95 / 5$ & 2 & $0.514 \mathrm{mS} / \mathrm{cm}$ \\
\hline
\end{tabular}

The gas composition was measured using quadrupole mass selective detector Hiden Analytical HPR-20 (Hiden Analytical, Warrington, UK) in the $m / z$ range 1-100. EEO was performed in glass reactor at $T=25{ }^{\circ} \mathrm{C}, p=1$ bar. To obtain information on types of chemical bonds presented in the porous layer, the samples were analyzed by infrared (IR) reflectance spectroscopy using Nicolet iS50 spectrometer (Thermo Fisher Scientific). 


\section{Results}

Figure 2 shows scanning electron micrograph (SEM) images of Si $\left(\begin{array}{lll}1 & 0 & 0\end{array}\right)$ surface with palladium clusters deposited during immersion in $\mathrm{PdCl}_{2}$ solution for $30 \mathrm{~min}$. The dimension of separate $\mathrm{Pd}$ particles varied in the range of $20<d<50 \mathrm{~nm}$. The agglomerates from the Pd particles varied in the range of $0.1<d<2 \mu \mathrm{m}$.

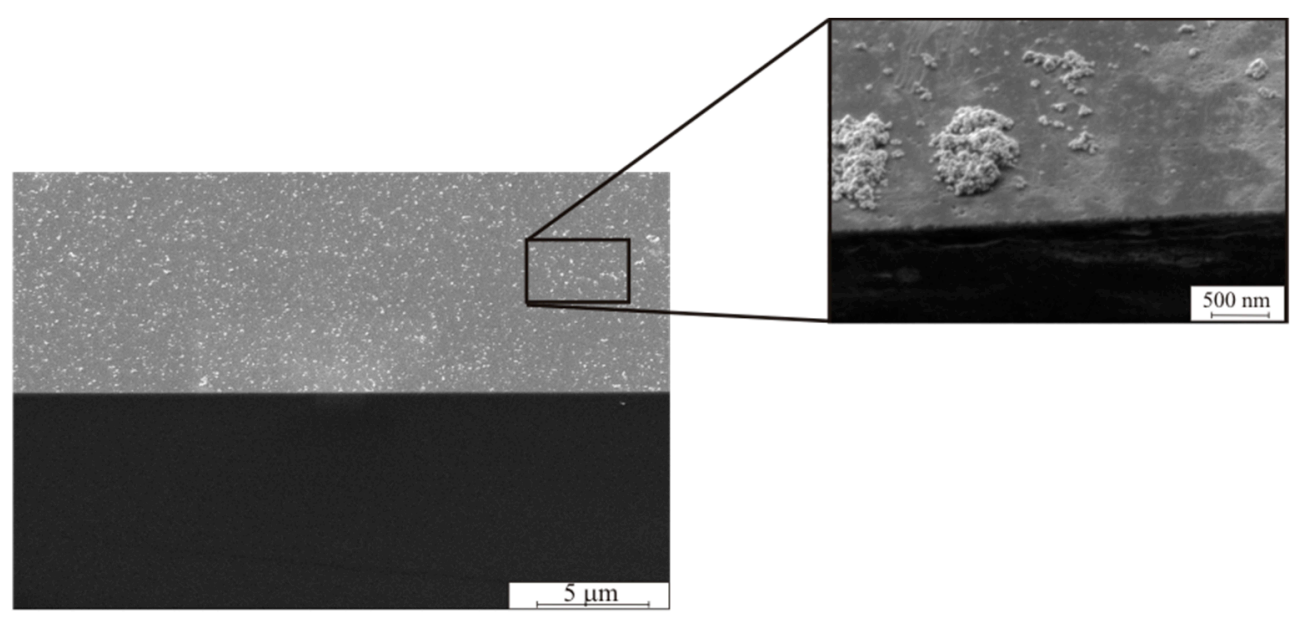

Figure 2. Scanning electron micrograph (SEM) image of Pd particles deposited on Si $\left(\begin{array}{llll}1 & 0 & 0\end{array}\right)$ wafer by immersing in $\mathrm{PdCl}_{2}: \mathrm{HCl}$ solution for $t=30 \mathrm{~min}$.

Figure 3 shows SEM images of the porous silicon surface after Pd nanoparticles-assisted chemical etching with different etching times.

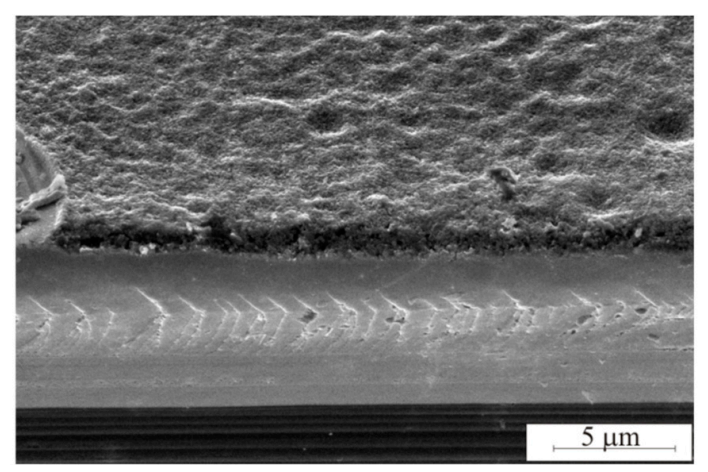

(a)

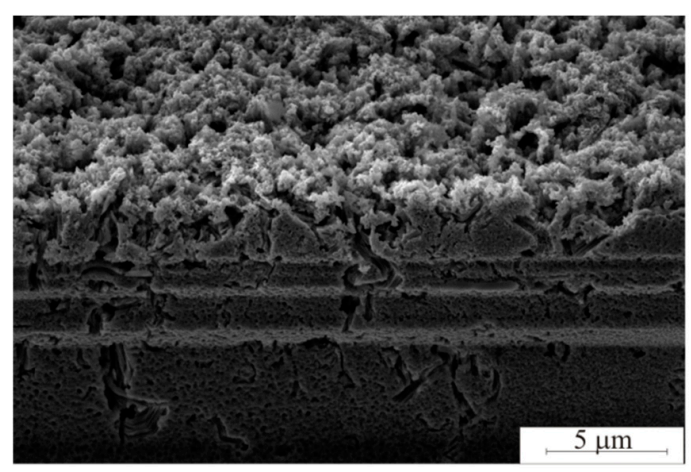

(b)

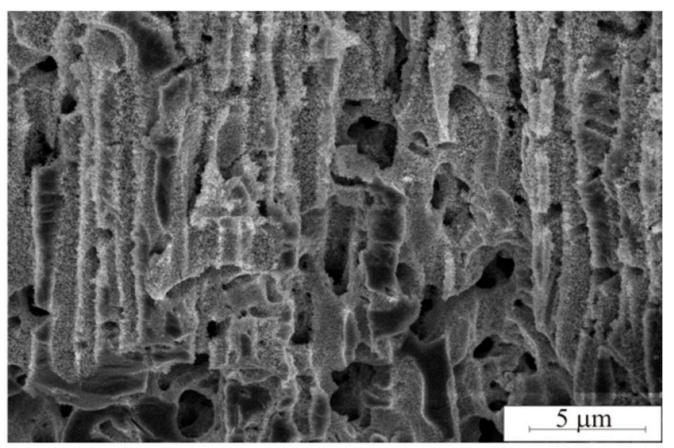

(c)

Figure 3. Scanning electron micrograph of the cross section porous silicon film etched for (a) $2 \mathrm{~min}$, (b) $15 \mathrm{~min}$ and (c) $120 \mathrm{~min}$ at $25^{\circ} \mathrm{C}$. 
Figure 3 illustrates porous silicon formation during different etching times. The minimum etching duration was $2 \mathrm{~min}$ because of $1.25 \mu \mathrm{m}$ porous layer is observed. The maximum etching duration was $120 \mathrm{~min}$. The porous layer breaks after $120 \mathrm{~min}$ etching. The porous silicon has perpendicular macropores with diameters from 1 to $3 \mu \mathrm{m}$ and mesopores tightly penetrating the walls of the porous matrix. Pd particles dissolve silicon, gradually plunging inwards and forming a pore. Parts of the particles were deposited on the pore walls during the etching process. This contributed to the formation of mesopores.

Each pore is characterised by the size and shape of the metal particle. The appearance of the inner pore cavity is a consequence of the etching. If the particle is agglomerated, the pore walls are like a sponge of mesoporous silicon. As the agglomerate moves deeper into the pore, individual particles with a diameter of $80 \pm 5 \mathrm{~nm}$ are deposited on the pore wall, contributing to its dissolution. This phenomenon is described in [12]. As particles are deposited on the walls, the agglomerate decreases in size, forming a dimple of a smaller diameter, which ultimately leads to the formation of a conical pore. In this case, the conical pore is due to the gradual dissolution of the walls (Figure 4a). Etching segments can determine the particle size. The upper part of the pore promotes its expansion with the solution penetrating the portion, uniformly dissolving the walls of the pore by photoelectrochemical dissolution. In the case of the separate metal particles, the pores will be formed vertically (Figure 4b). The pore diameter will be equal to the particle diameter.

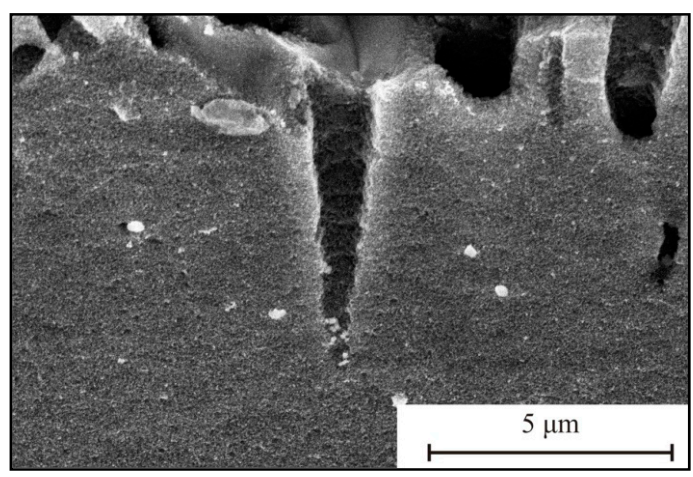

(a)

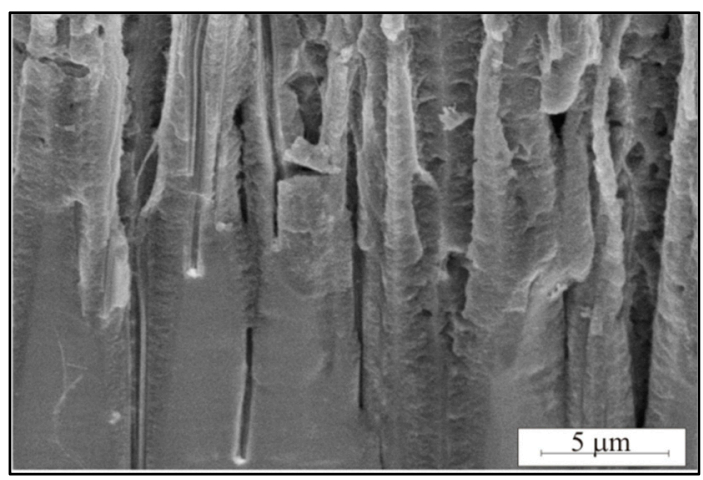

(b)

Figure 4. SEM image of cross section of sample after etching during $60 \mathrm{~min}$ : (a) the Pd particles are agglomerated, (b) the separate Pd particles.

It was found that Pd particles are present in the mesopores, which have access to a system por-Si/Pd. This system provides the ethanol electrooxidation (EEO). It can proceed according to one of a few schemes (Figure 5) [15]. The acetaldehyde, acetic acid (incomplete oxidation) and carbon dioxide (complete oxidation) are the products of electrooxidation of ethanol [16].

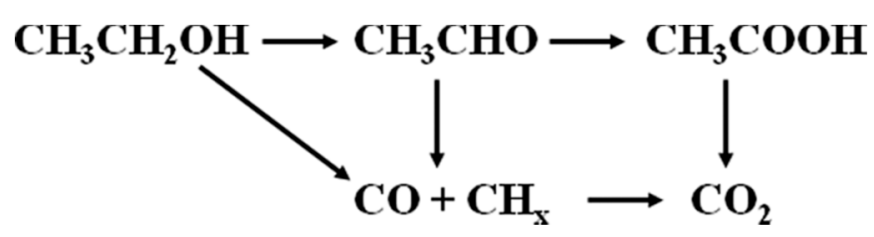

Figure 5. The scheme of the ethanol electrooxidation.

Figure 6a illustrates EEO. Intense gas evolution is observed from the functionalised metal-based silicon porous material immersed in ethanol solutions. Intense gas evolution gradually decreased. The gas evolution duration can be as long as several hours. The gas composition is shown in Figure 6b. 


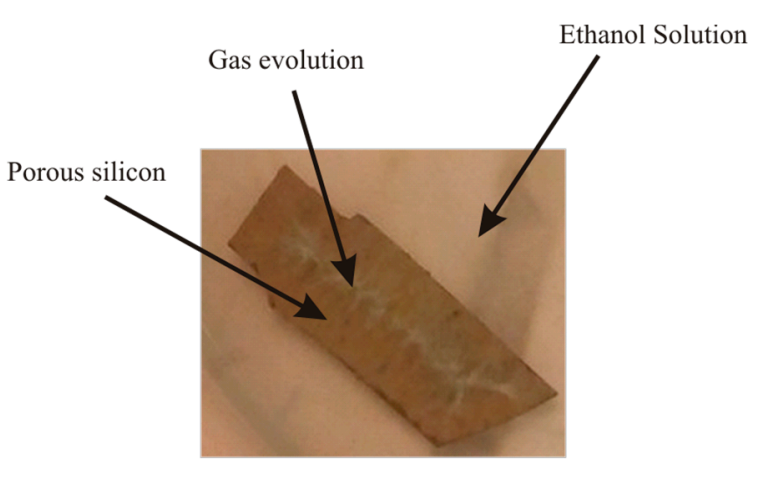

(a)

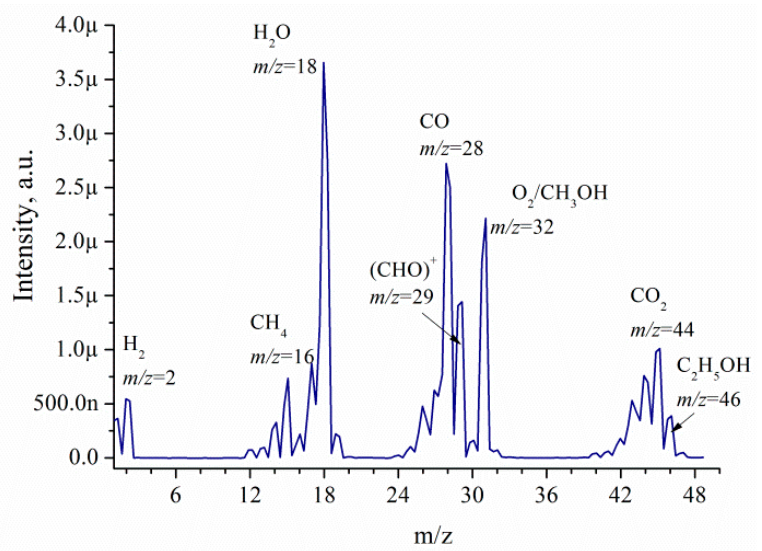

(b)

Figure 6. Electrooxidation (EEO): (a) sample photo during EEO, (b) the mass spectrum of a gas.

The mass spectrometry analysis of EEO products on por-Si/Pd shows that the main products are $\mathrm{CO}_{2}, \mathrm{CH}_{4}, \mathrm{H}_{2}, \mathrm{CO}, \mathrm{O}_{2}$, acetaldehyde $(\mathrm{CHO})^{+}$[17], methanol, ethanol and water vapor. The volumes of components relative to the total volume of EEO products are the following: $\mathrm{H}_{2}-5 \%$, $\mathrm{CH}_{4}-7 \%, \mathrm{H}_{2} \mathrm{O}-33 \%, \mathrm{CO}-25 \%, \mathrm{O}_{2}-20 \%, \mathrm{CO}_{2}-10 \%$. Figure $7 \mathrm{a}, \mathrm{b}$ shows the influence of the sample porosity, etching duration and temperature on the duration of gas evolution. In this work, intensive gas evolution can be visually detected without using additional devices.

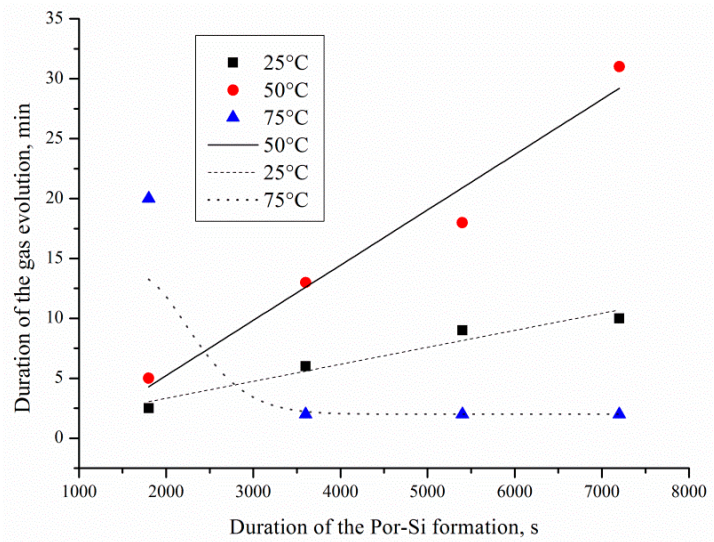

(a)

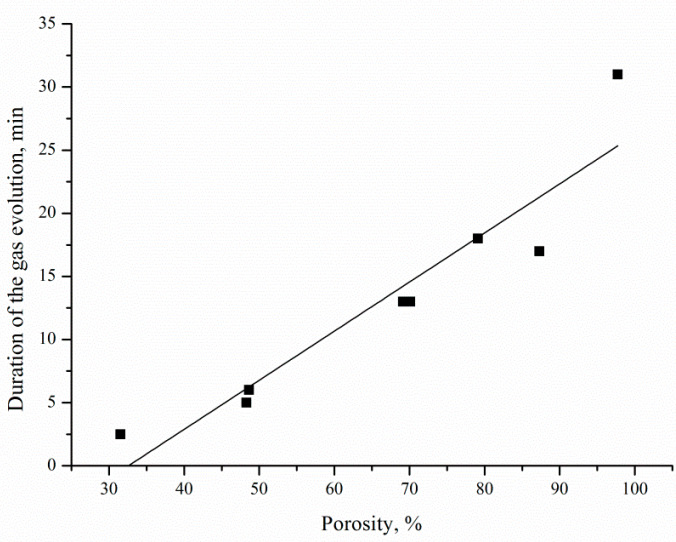

(b)

Figure 7. The dependence of the gas evolution on the (a) samples treatment duration, (b) por-Si porosity. Points are experimental results, lines are approximations.

It has been found that the maximum duration of intense gas evolution (32 $\mathrm{min}$ ) is observed for samples formed at $50{ }^{\circ} \mathrm{C}$ for $120 \mathrm{~min}$ etching, and the minimum duration $(2 \mathrm{~min})$ is observed for samples formed at $75^{\circ} \mathrm{C}$ for $60-120$ min etching. Increase and reduction of the duration of gas evolution is caused by the increase and reduction of porous silicon thickness respectively. It was established that a linear increase in the thickness of the porous layer happened with an increase in the etching duration from 30 to $120 \mathrm{~min}$ for temperatures of 25 and $50{ }^{\circ} \mathrm{C}$. The thickness of the porous layer was from 30 to $90 \mu \mathrm{m}$ for $30-120 \mathrm{~min}$ and $25{ }^{\circ} \mathrm{C}$ etching; from 60 to $105 \mu \mathrm{m}$ for $30-120 \mathrm{~min}$ and $50{ }^{\circ} \mathrm{C}$ etching; and from 100 to $45 \mu \mathrm{m}$ for $30-120 \mathrm{~min}$ and $75^{\circ} \mathrm{C}$ etching. It is due to porous layer dissolution. Reducing the porous silicon thickness leads to a decrease of the local metal/semiconductor and the EEO regions, respectively. The transfer of porous silicon at elevated processing temperatures is described in detail in [18]. The duration of the gas evolution is linearly dependent on the porosity of the layer. Therefore, the high porosity of the sample ensures access of the reactants to the surface of por-Si/Pd and removal of the reaction products. 
Besides the duration of gas evolution, an important parameter for establishing the EEO mechanism is the gas evolution rate. It characterises the EEO reaction rate. Table 2 shows the results of the analysis of the rate of gas evolution.

Table 2. The rate of gas evolution for three ethanol solutions.

\begin{tabular}{cccc}
\hline Volume Ratio $\mathrm{C}_{\mathbf{2}} \mathrm{H}_{\mathbf{5}} \mathrm{OH} / \mathbf{H}_{\mathbf{2}} \mathrm{O}$ & $\mathbf{9 5 / 5}$ & $\mathbf{6 0 / 4 0}$ & $\mathbf{3 0 / 7 0}$ \\
\hline \multirow{2}{*}{, $\mathbf{s}$} & 120 & 540 & 105 \\
& 360 & 900 & 870 \\
& 840 & 2550 & 2760 \\
\hline $\boldsymbol{V} \cdot \mathbf{1 0}^{-3}, \mathbf{c m}^{3} / \mathbf{s}$ & 19.8 & 4.3 & 22.6 \\
& 6.6 & 2.6 & 2.6 \\
& 2.8 & 1 & 0.8 \\
\hline
\end{tabular}

It has been found that the rate of gas evolution and the EEO is higher for solution 95/5. The high concentration of ethanol molecules promotes rapid adsorption. In addition, the rate of gas evolution is gradually reduced, which may be due to several factors:

1. solution depletion,

2. porous layer destruction,

3. contamination of the porous layer surface with reaction products.

The first two factors do not have an effect on the rate reduction. The porous layer destruction (SEM) and solution depletion has not been established. The addition of alcohol to the solution after the gas evolution stopped did not resume the process, while the as-prepared sample oxidized the spent solution. Treatment of the used sample in hydrofluoric acid contributed to the resumption of intense gas evolution in the spent solution.

Figure 8 shows SEM images of Pd/por-Si surface after EEO.

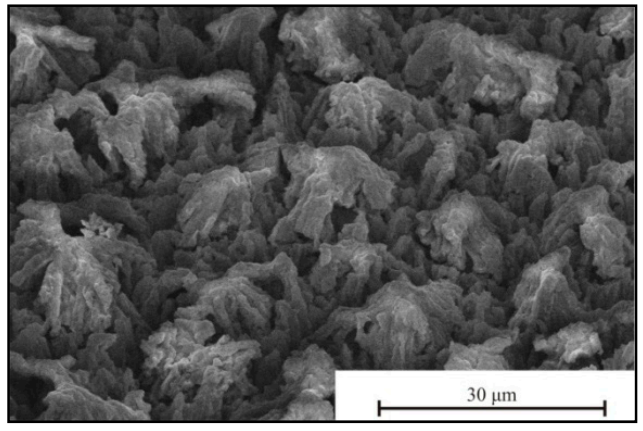

(a)

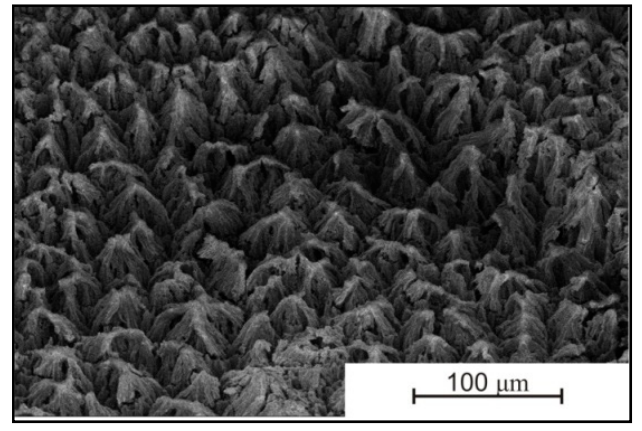

(b)

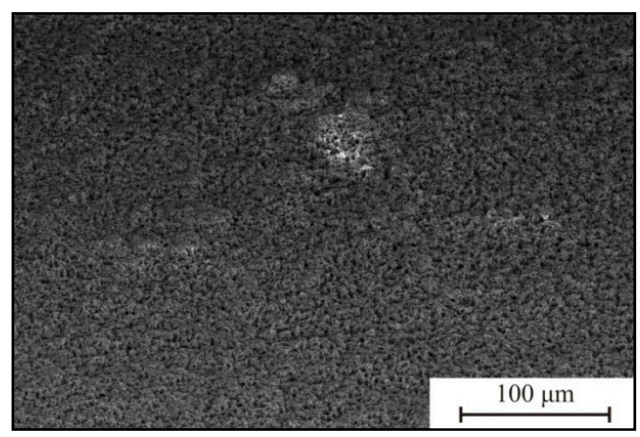

(c)

Figure 8. SEM images of porous silicon after EEO of solutions contained (a) 95/5, (b) 60/40 and (c) 30/70 ethanol/water at $25^{\circ} \mathrm{C}$ during $30 \mathrm{~min}$. 
In Figure 8, it can be seen that the gradual reduction of the gas evolution rate was due to contamination of the surface with reaction products. The higher the concentration of ethanol in the solution, the denser the precipitates. The thickness of the precipitate layer covering the porous layer has a value of several micrometres. The element analysis (EDX method) of the porous surface after EEO (Figure 9) allows us to determine a non-uniform distribution of elements into the surface. The elements in porous silicon are $\mathrm{Si}, \mathrm{O}$, and C (Table 3). The element in porous silicon at Spots 1, 3 and 4 is silicon.

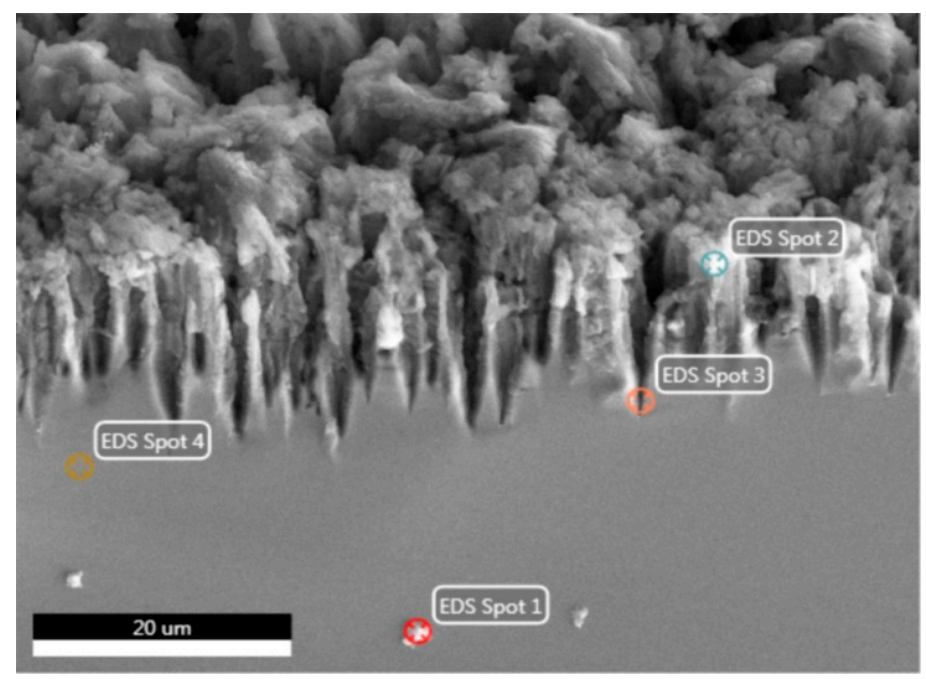

Figure 9. SEM image of porous silicon after electrooxidation and energy-dispersive X-ray (EDX) analysis spots.

Table 3. The element analysis of Spot 2 for porous silicon after 120 min electrooxidation of different solutions.

\begin{tabular}{cccc}
\hline Volume Ratio $\mathrm{C}_{\mathbf{2}} \mathbf{H}_{\mathbf{5}} \mathbf{O H} / \mathbf{H}_{\mathbf{2}} \mathbf{O}$ & Elements & Weight $\%$ & Atomic $\%$ \\
\hline \multirow{2}{*}{$95 / 5$} & $\mathrm{C}$ & 2.37 & 5.23 \\
& $\mathrm{O}$ & 3.33 & 5.53 \\
& $\mathrm{Si}$ & 94.30 & 89.23 \\
\hline \multirow{2}{*}{$60 / 40$} & $\mathrm{C}$ & 4.82 & 10.16 \\
& $\mathrm{O}$ & 8.35 & 13.23 \\
& $\mathrm{Si}$ & 86.83 & 76.61 \\
\hline \multirow{2}{*}{$30 / 70$} & $\mathrm{C}$ & 3.20 & 7.05 \\
& $\mathrm{O}$ & 2.56 & 4.23 \\
& $\mathrm{Si}$ & 94.23 & 88.71 \\
\hline
\end{tabular}

Chemical bonds between the components of the porous layer were analyzed by infrared (IR) reflectance spectroscopy (Figure 10).

IR reflection spectra show the presence of bands typical for EEO by Pt and Pd catalysts. Table 4 presents wavenumbers corresponding to the bonds.

The $\mathrm{CO}_{3}{ }^{2-}$ may be observed near $2846 \mathrm{~cm}^{-1}$. The acetate was displayed as two intense peaks at 1553 and $1410 \mathrm{~cm}^{-1}$. As the concentration of ethanol in solution increases, the acetate of $\mathrm{CH}_{3} \mathrm{COO}^{-}$ band $\left(1550 \mathrm{~cm}^{-1}\right)$ and $v(\mathrm{C}-\mathrm{H})$ of $\mathrm{CH}_{3} \mathrm{CH}_{2} \mathrm{OH}$ band $\left(2900 \mathrm{~cm}^{-1}\right)$ intensities also increase. As the concentration of ethanol in solution increases, the Si-H wag band intensities decrease. Decrease in intensity may be due to the increasing of the thickness of the precipitate layer covering the porous layer. 


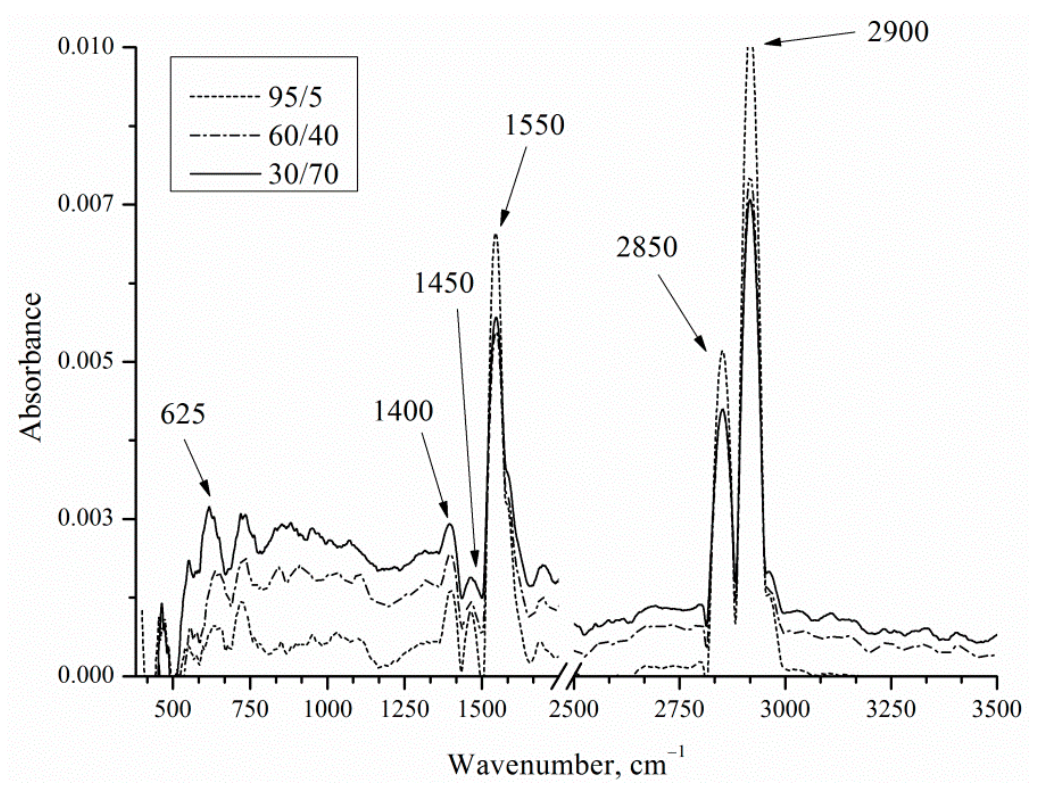

Figure 10. FTIR (Fourier-transform infrared) spectra of porous silicon after 120 min of electrooxidation of ethanol with different concentration.

Table 4. Surface bonding of porous silicon after electrooxidation (EEO).

\begin{tabular}{cc}
\hline Wave Number, $\mathbf{c m}^{-\mathbf{1}}$ & Bonds, Vibration Mode \\
\hline 625 & $\mathrm{Si}-\mathrm{H}$ wag [19] \\
\hline 1391 & $\delta(\mathrm{C}-\mathrm{H})$ of $\mathrm{CH}_{3} \mathrm{CH}_{2} \mathrm{OH}$ \\
\hline 1400 & acetate $v \mathrm{~s} \mathrm{CH}_{3} \mathrm{COO}^{-}[20]$ \\
\hline 1452 & $\delta(\mathrm{C}-\mathrm{H})$ of $\mathrm{CH}_{3} \mathrm{CH}_{2} \mathrm{OH}$ \\
\hline 1550 & acetate $v \mathrm{CH}_{3} \mathrm{COO}^{-}[20]$ \\
\hline 2850 & $\mathrm{CO}_{3}{ }^{2-}$ \\
\hline 2900 & $v(\mathrm{C}-\mathrm{H})$ of $\mathrm{CH}_{3} \mathrm{CH}_{2} \mathrm{OH}[21]$ \\
\hline
\end{tabular}

\section{Discussion}

The studies of EEO products on platinum catalysts using various analytical methods show that the reaction predominantly involves ethanol oxidation to $\mathrm{CO}_{2}$ [22]:

Anodic reaction on $\mathrm{Pd}$ :

$$
\mathrm{C}_{2} \mathrm{H}_{5} \mathrm{OH} \stackrel{2 \mathrm{e}}{\rightarrow} \mathrm{CH}_{3} \mathrm{OH} \stackrel{2 \mathrm{e}}{\rightarrow} \mathrm{CH}_{\mathrm{X}}+\mathrm{CO} \stackrel{8 \mathrm{e}}{\rightarrow} 2 \mathrm{CO}_{2}
$$

Cathodic reaction on $\mathrm{Si}$ :

$$
12 \mathrm{H}^{+}+3 \mathrm{O}_{2}+12 \mathrm{e}^{-} \rightarrow 6 \mathrm{H}_{2} \mathrm{O}
$$

$\mathrm{O}_{2}$ and $\mathrm{H}_{2}$ is a result of water splitting by porous silicon because of water solutions of ethanol [23]. Figure 11 shows the mass activity as a function of time on the $\mathrm{Pd} /$ porous silicon with a different thickness of por-Si for the solution No. 1-3. The mass activity characterises the amount of ethanol that was oxidized by the sample over a period of time $t$ and the behavior of the process. The measurement was performed in a two-electrode cell, $\mathrm{Pd} / \mathrm{Si}$ - anode, $\mathrm{Pt}$ - cathode. When the $\mathrm{Si} / \mathrm{Pd}$-system is dipped into the ethanol solution, EEO is occurred at the Pd/Si surface. The electrons' transport is going through the porous layer and silicon wafer. The electrons diffuse into the semiconductor and accumulated at the wafer's rear (unload) side. The current can be registered in the galvanic cell (Figure 10). The current flows through the electrolyte between the Pt-cathode and Si/Pd-anode. The Pt-electrode is arranged in the electrolyte in immediate proximity to the sample surface. 


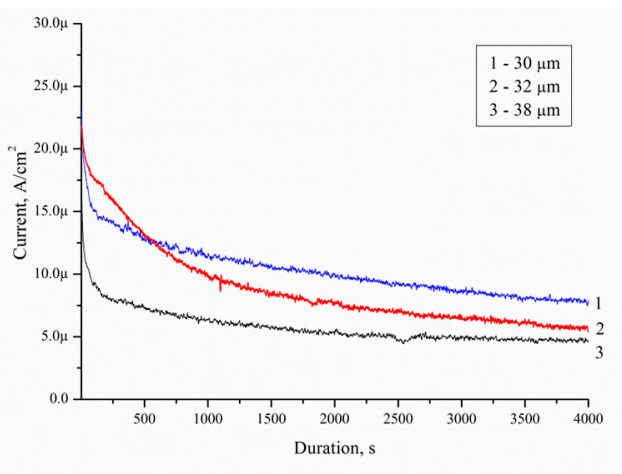

(a)

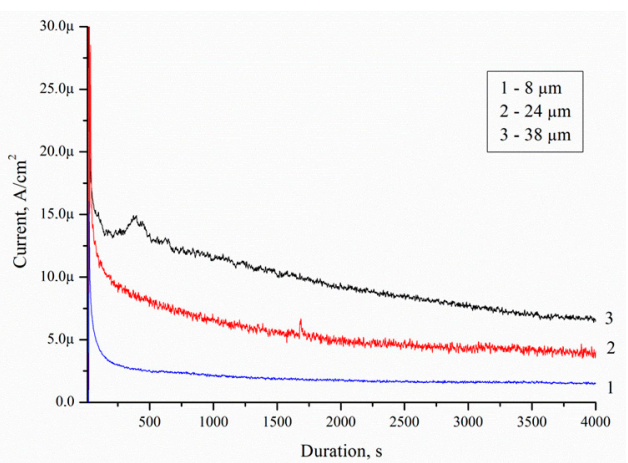

(b)

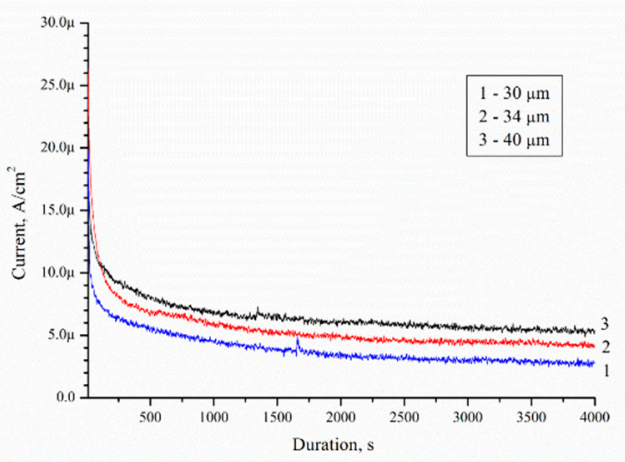

(c)

Figure 11. Current-time curves measured on Pd/por-Si for solutions: (a) No. 1 (10/90), (b) No. 2 (50/50) and (c) No. 3 (95/5).

The current density decreased with time for all porous samples and solutions. All catalysts showed the maximum current densities $\left(J_{\max }\right)$ immediately after the step (I section) (Figure 12). Then, the current decreased with time (II section). After a few minutes, the current achieved a pseudo-steady state (III section). The curve type corresponds to current-time curves measured during electrooxidation of dimethyl ether on $\mathrm{Pt} / \mathrm{C}$ and $\mathrm{PtMe} / \mathrm{C}$ catalysts in sulphuric acid [24].

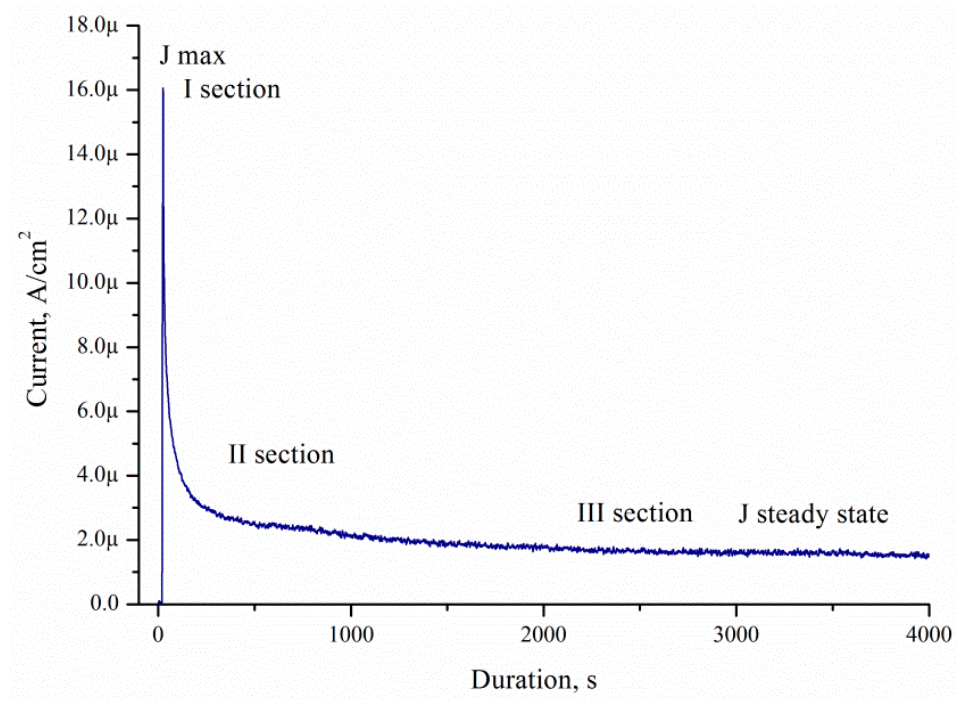

Figure 12. Typical $J(t)$ sections. 
Decrease of the current density is due to the formation of the contamination on the porous silicon surface. Table 5 shows the current-time curves analysis for different solutions.

Table 5. The current-time curves analysis for different solutions.

\begin{tabular}{cccc}
\hline Volume Ratio $\mathrm{C}_{\mathbf{2}} \mathrm{H}_{\mathbf{5}} \mathrm{OH} / \mathbf{H}_{\mathbf{2}} \mathbf{O}$ & Porous Silicon Thickness, $\mu \mathrm{m}$ & $J_{\max }, \mu \mathrm{A} / \mathbf{c m}^{2}$ & $J_{\text {steady state, }} \mu \mathrm{A} / \mathbf{c m}^{2}$ \\
\hline \multirow{2}{*}{$10 / 90$} & 30 & 23 & 8 \\
& 32 & 22 & 6 \\
& 38 & 17.5 & 5 \\
\hline \multirow{2}{*}{$50 / 50$} & 8 & 16 & 2 \\
& 24 & 52.5 & 3.5 \\
\multirow{2}{*}{$95 / 5$} & 38 & 77 & 7 \\
\hline & 30 & 54 & 3 \\
& 34 & 33 & 4.5 \\
& 40 & 79.6 & 5.5 \\
\hline
\end{tabular}

It was established that $J_{\max }$ depends on the thickness of the porous silicon and concentration of ethanol. Such dependence is due to the EEO reactions yield. In this case, the thickness of the porous layer affects the amount of Pd particles in the porous layer, due to the sample preparation. The minimum value of $J_{\max }$ and $J_{\text {steady state }}$ is observed for the case with a minimum porous layer thickness of $8 \mu \mathrm{m}$. The maximum values of $J_{\max }$ equal to 77 and $79.6 \mu \mathrm{A} / \mathrm{cm}^{2}$, and $J_{\text {steady state }}$ equal to 7 and $5.5 \mu \mathrm{A} / \mathrm{cm}^{2}$, are observed for $38-40 \mu \mathrm{m}$ thick porous layers. Ethanol concentration in solution does not affect $J_{\text {steady state, }}$ but affects $J_{\max }$. $J_{\max }$ reaches a value between 17 to $23 \mu \mathrm{A} / \mathrm{cm}^{2}$ for solution $10 / 90$. $J_{\max }$ reaches a value between 33 to $79.6 \mu \mathrm{A} / \mathrm{cm}^{2}$ for solution $95 / 5$. This may be due to the non-wettability of the surface of porous silicon formed Pd nanoparticles-assisted etching [25] by solution 95/5 and $50 / 50$ (the contact angles are $140^{\circ}$ ). The contact angle for solutions $10 / 90$ is $140^{\circ}$. The higher the ethanol concentration, the less the contact angle on porous surface [26]. Solution 10/90 showed the best activity for the electrooxidation in this study because of the high value of $J_{\text {steady state. }}$ Low surface contamination during electrooxidation (Figure 8c) facilitates ethanol access to the Pd surface, intensive mass transfer, and high $J_{\text {steady state }}$ value.

The corresponding charges from Figure 11 can be extracted and plotted versus a time scale to indicate the rate of formation of adsorbed species at this preparation potential of $\mathrm{Pd} /$ por-Si. The value

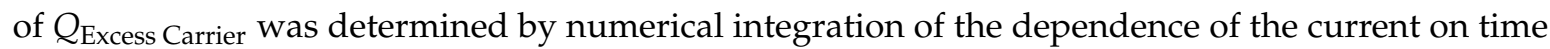
and presented in Figure 13. The $Q_{\text {Excess Carrier }}$ value is characterising excess charge carriers diffused into the substrate during EEO.

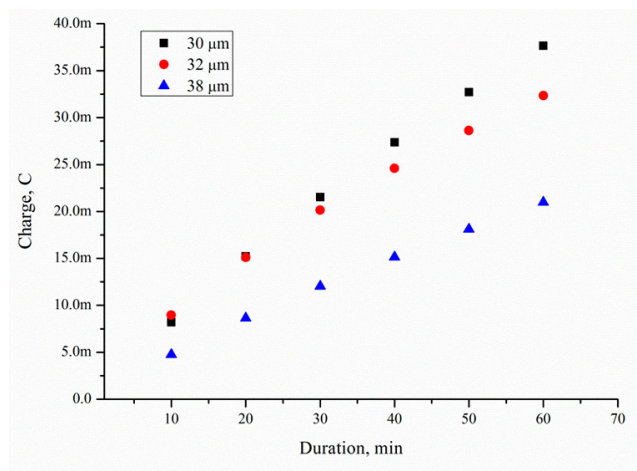

(a)

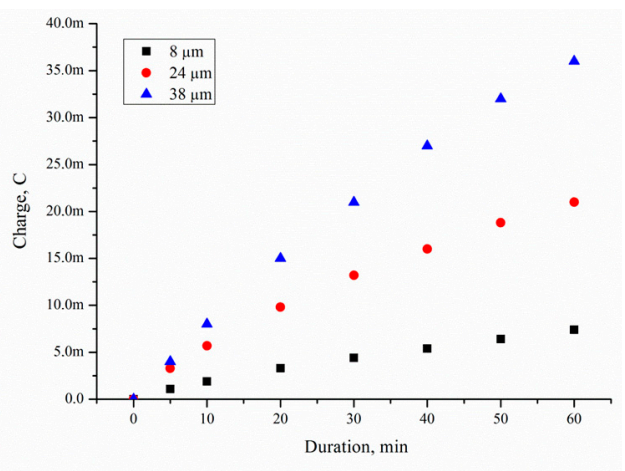

(b)

Figure 13. Cont. 


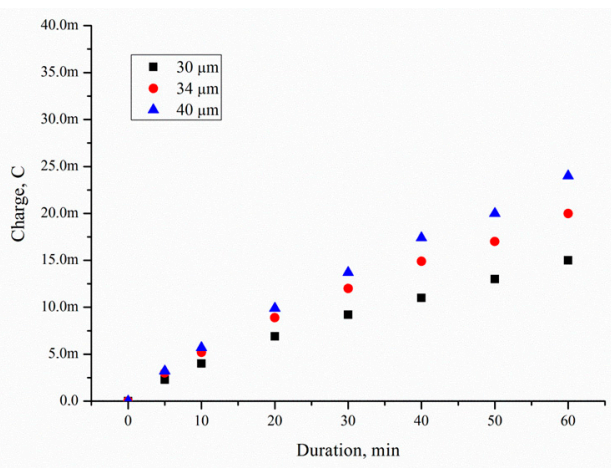

(c)

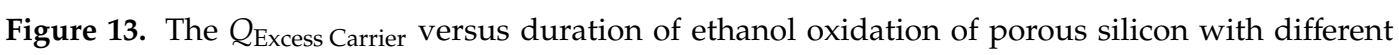
thickness and solution: (a) 10/90, (b) 50/50, (c) 95/5.

The charge of time is described by a polynomial of degree 2 with $R=0.99 \%$. The charge passing through the substrate $Q_{\text {Excess Carrier }}$ depends on a few factors: concentration of charge carriers injected into silicon $Q_{\text {total }}$, substrate thickness and specific resistivity $\left(Q_{\text {sub }}\right)$, and porous layer thickness $\left(Q_{\text {por-Si }}\right)$.

$$
Q_{\text {total }}=Q_{\text {Excess Carrier }}+Q_{\text {sub }}+Q_{\text {por }}
$$

$Q_{\text {total }}$ characterises the value of all charge carriers involved in the electrooxidation of ethanol. It the case of the present research work, $Q_{\text {total }}$ depends on Pd/por-Si contact area. The increase in charge carrier concentration on the surface of the hole, caused by injection, leads to the appearance of a diffusion electron flow directed along the $\mathrm{x}$-axis perpendicular to the semiconductor surface, with the result that the carrier concentration increases not only on the surface but also in the depth of the semiconductor. In this case, injected carriers go deeper into the semiconductor at different distances, where they are recombined.

Figure 14 shows current-time curves measured on Pd/por-Si for different solutions at $25^{\circ} \mathrm{C}$. A decrease in the wafer thickness by $70 \mu \mathrm{m}$, with the same thickness of porous silicon $30 \mu \mathrm{m}$, increases the charge from 36 to $140 \mathrm{mC}$ for solution 10/90, from 20 to $100 \mathrm{mC}$ for solution 50/50, and from 14 to $72 \mathrm{mC}$ for solution $95 / 5$ at 3600 s oxidation.

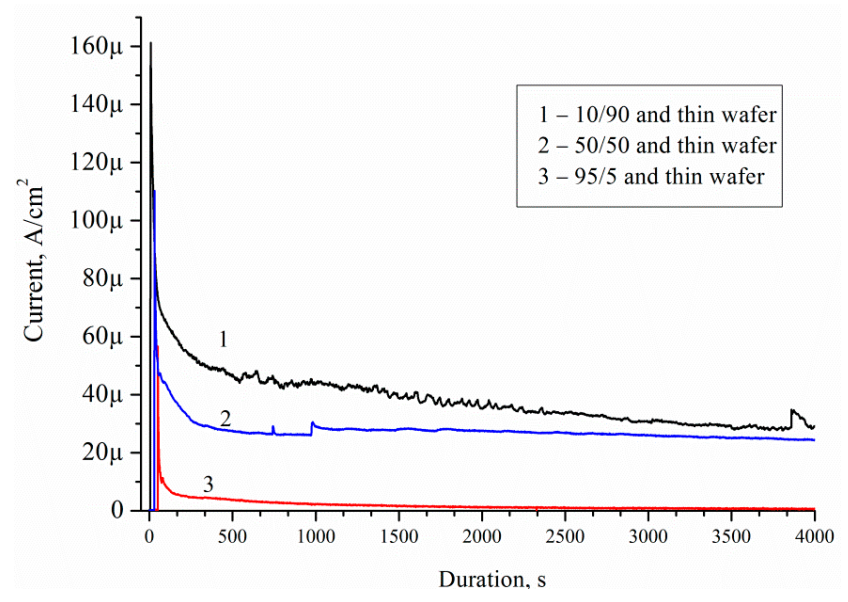

Figure 14. Current-time curves measured on Pd/por-Si for solutions: 10/90, 50/50 and 95/5.

Having excluded the contribution of the thickness and resistivity of a single crystal silicon wafer, as well as the thickness of the porous layer because of equal value, we can obtain the equation:

$$
Q_{\text {total } n}-Q_{\text {Excess Carrier } n}=Q_{\text {total } m}-Q_{\text {Excess Carrier } m}
$$


where $n$ and $m$ are the solutions number, and $Q_{\text {Excess Carrier }}$ is measured by short-circuit current in the galvanic cells. We can calculate $Q_{\text {total }}$ for unknown solutions for any duration, using the same porous silicon samples and one test solution with $Q_{\text {total }}$.

This approach can be used for porous silicon formation by Pd nanoparticles-assisted etching. The process of forming a porous layer is identical, with the only difference being that the thickness of the initial single crystal is $525 \mu \mathrm{m}$ (Figure 15a) and $336 \mu \mathrm{m}$ (Figure 15b), respectively.

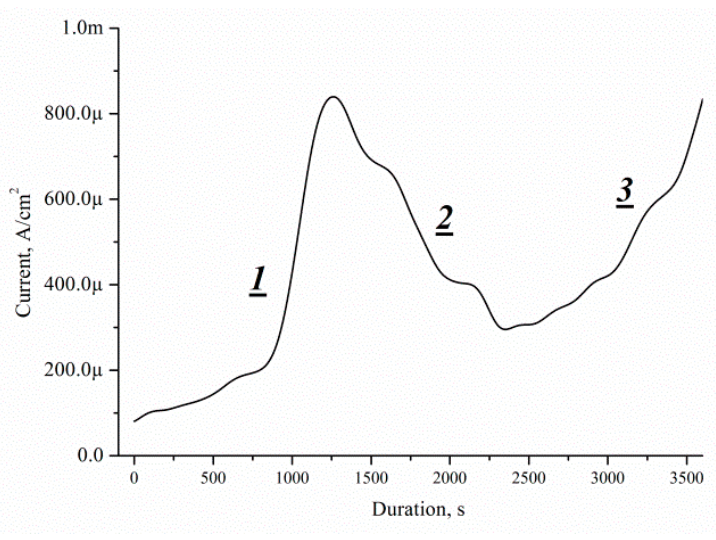

(a)

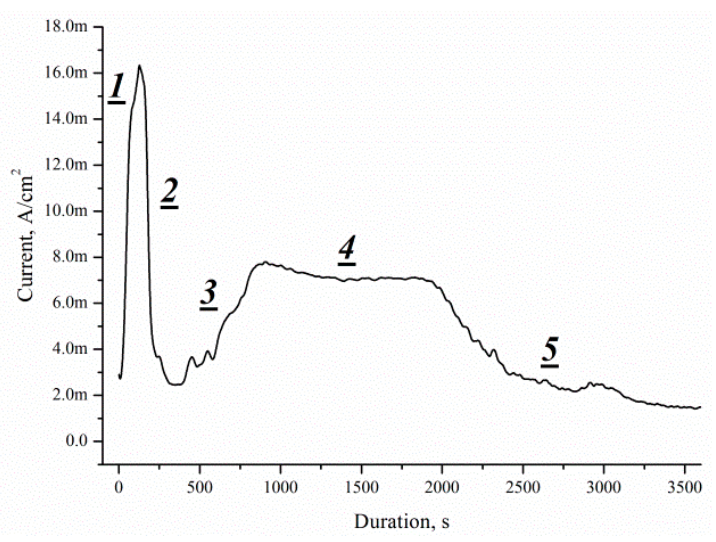

(b)

Figure 15. Current-time curves measured during Pd nanoparticles-assisted etching of silicon with thickness: (a) $525 \mu \mathrm{m}$, (b) $336 \mu \mathrm{m}$.

The $J(t)$ curves characterise the etching mechanism. Five characteristic regions can be identified:

(I) current increasing,

(II) slowing growth rate and subsequently decreased current,

(III) current increasing,

(IV) constant current,

(V) current decreasing.

$J(t)$ reflects a change of the area $(S)$ of the electrochemical reaction front. The changes of $J$ with time (Figure 14) are related to the evolution of the Si morphology during pore nucleation. Pore formation takes place after the immersion of silicon into the solution containing $\mathrm{HF}$ and $\mathrm{H}_{2} \mathrm{O}_{2}$. The pore area depends on the duration of the treatment [27]. The increase in the surface area leads to the growth of the current density, the first region.

The current growth continues until a porous layer of critical thickness is formed on the Si surface. In this case, access of the solution to the surface of monocrystalline silicon becomes limited. The transport of holes through porous silicon is difficult due to the high specific resistance of the por-Si [27]. With an increase in the thickness of the porous layer, the concentration of excess holes that are not involved in the dissolution of Si becomes smaller, the second region. A further effect of the solution on the surface leads to the dissolution of the porous layer (the beginning of region III). Dissolution of por-Si reduces the thickness of the porous layer to less than the critical value, which increases the concentration of holes in Si, and, consequently, the current in region III. The current is constant in region IV due to the growth and etching of the porous silicon. The porous layer growth and current decrease in the region $\mathrm{V}$.

The charge of the first cycle (single crystal is $525 \mu \mathrm{m}$ ) takes the value of $1.5 \mathrm{C}$, while the second (single crystal is $336 \mu \mathrm{m}$ ) 17.7 C. Thus, in a single crystal $189 \mu \mathrm{m}$ thick with a specific resistance of $0.01 \Omega \cdot \mathrm{cm}$, carriers of charge of $16.2 \mathrm{C}$ recombine. Removing silicon can increase the charge passing through the sample by 11.8 times. The currents of the second cycle have values exceeding the currents of the first cycle and allow a detailed study of the structural change during Pd nanoparticles-assisted chemical etching of silicon. 


\section{Conclusions}

It is shown that por-Si, formed by Pd nanoparticles-assisted chemical etching, has the property of ethanol electrooxidation. Intense gas evolution is observed from the metal/porous silicon immersed in ethanol solutions. The chromatographic analysis of EEO products on por-Si/Pd shows that the main products are $\mathrm{CO}_{2}, \mathrm{CH}_{4}, \mathrm{H}_{2}, \mathrm{CO}, \mathrm{O}_{2}$, methanol and water vapor. The duration of the gas evolution is linearly dependent on the porosity of the layer. Therefore, the high porosity of the sample ensures access of the reactants to the surface of por-Si/Pd and removal of the reaction products. The gradual reduction of the gas evolution rate was due to contamination of the surface with reaction products. The mass activity, as a function of time, was measured by the short-circuit current in the galvanic cells.

It was established that $J_{\max }$ depends on the thickness of the porous silicon and concentration of ethanol. Such dependence is due to the EEO reactions yield. In this case, the thickness of the porous layer affects the amount of $\mathrm{Pd}$ particles in the porous layer, due to the sample preparation. The minimum value of $J_{\max }$ and $J_{\text {steady state }}$ is observed for the case with a minimum porous layer thickness of $8 \mu \mathrm{m}$. The maximum value of $J_{\max }$ equals to 77 and $79.6 \mu \mathrm{A} / \mathrm{cm}^{2}$, and for $J_{\text {steady state }}$ equals to 7 and $5.5 \mu \mathrm{A} / \mathrm{cm}^{2}$, is observed for 38-40 $\mu \mathrm{m}$ thick porous layers. Ethanol concentration in solution does not affect $J_{\text {steady state, }}$ but affects $J_{\max }$. $J_{\max }$ reaches a value between 17 to $23 \mu \mathrm{A} / \mathrm{cm}^{2}$ for solution $10 / 90$. $J_{\max }$ reaches a value between 33 to $79.6 \mu \mathrm{A} / \mathrm{cm}^{2}$ for solution $95 / 5$.

A decrease in the wafer thickness by $70 \mu \mathrm{m}$, with the same thickness of porous silicon, increases the charge carriers, diffused into the substrate, from 36 to $140 \mathrm{mC}$ for solution 10/90, from 20 to $100 \mathrm{mC}$ for solution 50/50, and from 14 to $72 \mathrm{mC}$ for solution $95 / 5$ at 3600 s oxidation. Thus, the porous silicon thickness, porosity and solution composition are the main factors defined EEO efficiency.

Author Contributions: Conceptualization, O.V.; methodology, O.V. and S.G.; validation, O.V.; formal analysis, O.V.; investigation, G.S., T.M. and A.D.; resources, O.V., T.M. and A.D.; writing—original draft preparation, O.V.; writing-review and editing, S.G. and T.M.; visualization, O.V.; supervision, S.G.; funding acquisition, O.V.

Funding: This investigation was supported by the Russian Science Foundation (project No. 19-79-00205).

Conflicts of Interest: The authors declare no conflicts of interest.

\section{References}

1. Minh, N.; Shirley Meng, Y. Future energy, fuel cells, and solid-oxide fuel-cell technology. MRS Bull. 2019, 44, 682-683. [CrossRef]

2. Murdoch, M.; Waterhouse, G.I.N.; Nadeem, M.A.; Metson, J.B.; Keane, M.A.; Howe, R.F.; Llorca, J.; Idriss, H. The effect of gold loading and particle size on photocatalytic hydrogen production from ethanol over $\mathrm{Au} / \mathrm{TiO}{ }_{2}$ nanoparticles. Nat. Chem. 2011, 3, 489-492. [CrossRef]

3. Demirbas, A. Comparison of transesterification methods for production of biodiesel from vegetable oils and fats. Energy Convers. Manag. 2008, 49, 125-130. [CrossRef]

4. Pichonat, T.; Bernard, G.-M. Realization of porous silicon based miniature fuel cells. J. Power Sources 2006, 154, 198-201. [CrossRef]

5. Karbassian, F.; Rajabali, S.; Chimeh, A.; Mohajerzadeh, S.; Asl-Soleimani, E. Luminescent porous silicon prepared by reactive ion etching. J. Phys. D Appl. Phys. 2014, 47, 385103-385111. [CrossRef]

6. Barillaro, G.; Nannini, A.; Piotto, M. Electrochemical etching in HF solution for silicon micromachining. Sens. Actuators A Phys. 2002, 102, 195-201. [CrossRef]

7. Lehmann, V.; Föll, H. Formation Mechanism and Properties of Electrochemically Etched Trenches in n-Type Silicon. J. Electrochem. Soc. 1990, 137, 653-659. [CrossRef]

8. Gavrilov, S.A.; Karavanskii, V.A.; Sorokin, I.N. Effect of the electrolyte composition on properties of porous silicon layers. Russ. J. Electrochem. 1999, 35, 729-734.

9. Akan, R.; Parfeniukas, K.; Vogt, C.; Toprak, M.S.; Vogt, U. Reaction control of metal-assisted chemical etching for silicon-based zone plate nanostructures. RSC Adv. J. 2018, 9, 12628-12634. [CrossRef]

10. Pyatilova, O.; Gavrilov, S.; Savitskiy, A.; Dudin, A.; Pavlov, A.; Shilyaeva, Y. Investigation of porous Si formed by metal-assisted chemical etching with Au as catalyst. J. Phys. Conf. Ser. 2017, 829, 1. [CrossRef] 
11. Kumar, J.; Ingole, S. Effect of Silicon Conductivity and $\mathrm{HF} / \mathrm{H}_{2} \mathrm{O}_{2}$ Ratio on Morphology of Silicon Nanostructures Obtained via Metal-Assisted Chemical Etching. J. Electron. Mat. 2018, 47, 1583-1588. [CrossRef]

12. Yae, S.; Morii, Y.; Fukumuro, N.; Matsuda, H. Catalytic activity of noble metals for metal-assisted chemical etching of silicon. Nanoscale Res. 2012, 7, 352-357. [CrossRef]

13. Zhu, B.; Lund, P.; Raza, R.; Ma, Y.; Fan, L.; Afzal, M.; Patakangas, J.; He, Y.; Zhao, Y.; Tan, W.; et al. Schottky Junction Effect on High Performance Fuel Cells Based on Nanocomposite Materials. Adv. Energy Mat. 2015, 5, 1401895-1401901. [CrossRef]

14. Dzhafarov, T.; Yuksel, S.; Aydin, M. Nanoporous Silicon-Based Ammonia-Fed Fuel Cells. Mater. Sci. Appl. 2014, 5, 1020-1026. [CrossRef]

15. Liang, Z.; Zhao, T.; Xu, J.; Zhu, L. Mechanism study of the ethanol oxidation reaction on palladium in alkaline media. J. Electrochem. Acta 2009, 54, 2203-2208. [CrossRef]

16. Farsadrooh, M.; Torrero, J.; Pascual, L.; Peña, M.A.; Retuerto, M.; Rojas, S. Two-dimensional Pd-nanosheets as efficientelectrocatalysts for ethanol electrooxidation. Evidences of the C-C scission at low potentials. Appl. Catal. B Environ. 2018, 237, 866-875. [CrossRef]

17. Ju, K.S.; Pak, S.N.; Ri, C.N.; Ryo, H.S.; Kim, K.-I.; So, S.-R.; Ri, C.-K.; Ri, S.-P.; Nam, K.-W.; Pak, K.-S.; et al. Ethanol electro-oxidation on carbon-supported Pt1Mn3 catalyst investigated by pinhole on-line electrochemical mass spectrometry. Chem. Phys. Lett. 2019, 727, 78-84. [CrossRef]

18. Backes, A.; Leitgebz, M.; Bittner, A.; Schmid, U. Temperature Dependent Pore Formation in Metal Assisted Chemical Etching of Silicon. J. Solid State Sci. Technol. 2016, 5, 653-656. [CrossRef]

19. Canham, L. Handbook of Porous Silicon; Springer: Basel, Switzerland, 2018.

20. Christensen, P.A.; Jones, S.W.M.; Hamnett, A. In Situ FTIR Studies of Ethanol Oxidation at Polycrystalline Pt in Alkaline Solution. J. Phys. Chem. C 2012, 116, 24681-24689. [CrossRef]

21. Iwasita, T.; Pastor, E. A dems and FTir spectroscopic investigation of adsorbed ethanol on polycrystalline platinum. Electrochim. Acta 1994, 39, 531-537. [CrossRef]

22. Teng, X. Anodic Catalyst Design for the Ethanol Oxidation Fuel Cell Reactions. Mater. Sci. 2013, $473-484$.

23. Dai, F.; Zai, J.; Yi, R.; Gordin, M.L.; Sohn, H.; Chen, S.; Wang, D. Bottom-up synthesis of high surface area mesoporous crystalline silicon and evaluation of its hydrogen evolution performance. Nat. Commun. 2014, 5, 3605. [CrossRef]

24. Liu, Y.; Mitsushima, S.; Ota, K.-I.; Kamiya, N. Electro-oxidation of dimethyl ether on Pt/C and PtMe/C catalysts in sulfuric acid. Electrochim. Acta 2006, 51, 6503-6509. [CrossRef]

25. Volovlikova, O.V.; Gavrilov, S.A.; Silakov, G.O.; Zheleznyakova, A.V.; Dudin, A.A. Preparation of Hydrophobic Porous Silicon by Metal-assisted Etching with Pd-Catalyst. Russ. J. Electrochem. 2019, 55, 1186-1195.

26. Volovlikova, O.V.; Silakov, G.O.; Gavrilov, S.A.; Dudin, A.A.; Diudbin, G.O.; Shilyaeva, Y.I. Investigation of the Morphological Evolution and Etching Kinetics of black Silicon During Ni-Assisted Chemical Etching. J. Phys. Conf. Ser. 2018, 987, 012039. [CrossRef]

27. Bisi, O.; Ossicini, S.; Pavesi, L. Porous silicon: A quantum sponge structure for silicon based optoelectronics. Surf. Sci. Rep. 2000, 38, 1-126. [CrossRef]

(C) 2019 by the authors. Licensee MDPI, Basel, Switzerland. This article is an open access article distributed under the terms and conditions of the Creative Commons Attribution (CC BY) license (http://creativecommons.org/licenses/by/4.0/). 